\title{
The Inner Circle Revisited The Case of an Egalitarian Society
}

Grau Larsen, Anton; Ellersgaard, Christoph

Document Version

Accepted author manuscript

Published in:

Socio-Economic Review

DOI:

10.1093/ser/mwx052

Publication date:

2018

License

Unspecified

Citation for published version (APA):

Grau Larsen, A., \& Ellersgaard, C. (2018). The Inner Circle Revisited: The Case of an Egalitarian Society. SocioEconomic Review, 16(2), 251-275. https://doi.org/10.1093/ser/mwx052

Link to publication in CBS Research Portal

\section{General rights}

Copyright and moral rights for the publications made accessible in the public portal are retained by the authors and/or other copyright owners and it is a condition of accessing publications that users recognise and abide by the legal requirements associated with these rights.

Take down policy

If you believe that this document breaches copyright please contact us (research.lib@cbs.dk) providing details, and we will remove access to the work immediately and investigate your claim. 


\section{The Inner Circle Revisited: \\ The Case of an Egalitarian Society \\ Anton Grau Larsen and Christoph Ellersgaard}

Journal article (Accepted manuscript* ${ }^{*}$

\section{Please cite this article as:}

Grau Larsen, A., \& Ellersgaard, C. (2018). The Inner Circle Revisited: The Case of an Egalitarian Society. SocioEconomic Review, 16(2), 251-275. https://doi.org/10.1093/ser/mwx052

This is a pre-copyedited, author-produced version of an article accepted for publication in Socio-Economic Review following peer review. The version of record is available online at:

\section{DOl: dx.doi.org/10.1093/ser/mwx052}

* This version of the article has been accepted for publication and undergone full peer review but has not been through the copyediting, typesetting, pagination and proofreading process, which may lead to differences between this version and the publisher's final version AKA Version of Record.

Uploaded to CBS Research Portal: July २०19 


\title{
The inner circle revisited
}

\section{The case of a negotiated economy}

\begin{abstract}
The interlocks within the corporate elite in a highly egalitarian society, the negotiated economy of the Scandinavian welfare state of Denmark, are examined by critically reassessing Michael Useem's notion of the inner circle. Using a new measure of social circles memberships based on proximity in social networks, we identify a cohesive core group of 171 individuals within a corporate elite of 6,154 board members of the top 1,037 Danish corporations. A high degree of social homogeneity in gender, social background, education, and career position underlines the cohesion of the inner circle. By mapping business association committees, political commissions, university governing boards, cultural institutions, social clubs, foundations, and royal events, the inner-circle members are shown to be representatives of the entire capitalist class in key sectors. This suggests that on-going opposition to the capitalist class enhances the need for collective action, and thus paradoxically strengthens the unity of the corporate elite.
\end{abstract}

Keywords: elites, welfare state, social networks, social capital, Scandinavia, class

JEL classification: C38 Classification Methods, L14 Transactional Relationships, D72 Political Processes 
In the wake of the financial crisis of 2008 and the subsequent downturn in the global economy, the familiar spectre of the corporate elites, upper classes, the ultra-rich, and the capitalist class returned to haunt society again. However, as argued by Mark Mizruchi (2013), the organization of the capitalist class, and in particular what Michael Useem (1984) identifies as the 'inner circle'-the interconnected and politically active elite among corporate directors - has changed profoundly. Even if the most privileged sections of society hoard an increasing share of wealth and income, as shown by Thomas Piketty (2014) and others, the corporate elite paradoxically is now fragmented and no longer has an organized capacity to act in a concerted fashion. Mizruchi (2013) identifies the growing power of individual corporations and the lack of organized resistance, whether from state actors or labor unions, as key reasons for the fragmentation of the corporate network, leading to a narrow focus on the management and shareholder returns of individual corporations rather than broader business objectives (Useem, 2015).

The negotiated economy of the relative egalitarian welfare states of Scandinavia who still has high levels of labor union density and relatively strong states provides an interesting case of capitalist class organization. Have higher levels of political resistance actually kept the inner circle alive? Traditionally, elite cohesion in Scandinavia is generally viewed as most improbable, and, of these countries, Denmark in particular has been regarded as, if not a pluralist haven, then at least one with relatively weak elite coherence and high openness in recruitment (Christiansen \& Togeby, 2007; Ruostetsaari, 2007). Little is known of the strength of corporate interlocks, though, and in particular how they relate to the political representation of the capitalist class in Denmark. The sparse research on Danish corporate interlocks and interlockers does suggest a high, if declining, degree of clustering (Edling, Hobdari, Randøy, Stafsudd \& Thomsen, 2012; Schøtt, 2003). Ultimately, however, the social 
organization of the corporate elite after the financial crisis in the context of this negotiated economy has yet to be explored in depth.

The primary aim of this study, then, is to critically reassess the concept of the inner circle in the political economy of contemporary Denmark, and to understand the conditions under which the organization of the corporate elite takes the form of an inner circle. Adding to this, we use a methodological procedure capable of both identifying the inner circle, and assessing its social cohesion and opportunity for political action, far more in line with the theoretical arguments used by Useem. Originally, Useem (1984, p. 63) for 'technical convenience’ used multiple board memberships of top corporate boards as a proxy of inner-circle membership; however, a more empirically sensitive procedure for identifying the intersection of social circles using social network analysis was developed by Richard Alba and Charles Kadushin (1976). When investigating the inner circle by applying this method to the network of multiple board members of the top 1,037 Danish corporations, a core group became visible. Having identified this inner circle, the social homogeneity of its members' biographies was assessed, and the political activity of the inner circle demonstrated by mapping their participation in other potentially powerful networks, drawing on unique data on all institutionalized influence networks in Denmark. Thus we ask whether members of an inner circle, identified only by their positions in the corporate network, are more likely to be part of other important elite networks, with all that means in terms of structural opportunities to influence the governance of other power spheres.

\section{Background: The fracturing of the inner circle in contemporary capitalism}

In a number of countries the level of integration within the corporate elite's inner circle has deteriorated. This has been linked to two coinciding developments: changes in network 
ecology tied to the related decline of bank involvement in corporate networks, with the emergence of transnational corporate networks and new standards of corporate governance; and the lack of organized challenges to corporate interests. As they operate at different empirical levels, they can easily be part of the same process. We will now show how, both with regard to the challenges posed by a changing network ecology and the level—and type-of the political opposition, Denmark is swimming against the current.

Firstly, as the American interlocks were bound up with one another thanks to bank centrality (see Mariolis, 1975; Mizruchi, 1982), the disengagement of banks led to decline in network cohesion in the US corporate network (Barnes \& Ritter, 2001; Davis \& Mizruchi, 1999). In Denmark, corporate law has since 1930 prohibited bank directors from sitting on boards outside the financial sector (Edling et al., 2012). As a result, the corporate network has not relied on banks to the same extend. Therefore a change in the banks' network strategies is unlikely to have had much impact on the organization of the corporate network.

Secondly, small, open economies such as the Netherlands and Switzerland, both comparable to the Danish economy, have experienced a decline in the number of corporate interlocks (Bühlmann, David, \& Mach, 2012; Heemskerk, 2007; Heemskerk \& Fennema, 2009; Heemskerk \& Schnyder, 2008). As is the case in the crumbling of the US corporate network the weakening of ties in the smaller economies can be explained by the banks turning their attention away from productive capital. However, it seems, in part, to be related to the influx of foreign capital. Foreign ownership will usually result in foreign directors and board members. As national networks in some smaller nation-states decline and others become less hierarchical, we see the rise of new trans-European or global elites that comprise 'global interlockers' (Carroll, 2010; Heemskerk, Fennema, \& Carroll, 2016). However, integration in trans-European or transnational interlocks appears to vary considerably (Vion, Dudouet, \& 
Grémont, 2015) and Denmark is still on the periphery of European corporate elite formation (van Veen \& Kratzer, 2011). Furthermore, both the Netherlands and Switzerland are home to several of the world's largest corporations, whereas Danish corporations are comparatively small, with the exception of the giant shipping conglomerate A.P. Møller-Mærsk, the only Danish corporation listed in Fortune's Global 500 (the Netherlands has eleven such corporations on the list and Switzerland fourteen). The Danish case thus sheds light on whether the inner circle has also corroded within economies with relatively small corporations. $^{1}$

Thirdly, the changes to international standards of corporate governance (see, for example, Ferris, Jagannathan, \& Pritchard, 2003) and shareholder value have called into question the legitimacy of old boys' network and having too many board memberships (Chu \& Davis, 2016), but in in Denmark the greater challenge stems from ideological concerns, and not direct interest in ownership, as Danish corporations have not yet been subject to dispersed shareholding. Of the top 82 corporations in 2008, 25 were controlled by families, 15 were controlled by foundations, 6 were state-owned, and 9 were owned by cooperatives (Ellersgaard, Larsen \& Munk, 2013). Of the 1,037 corporations included in this study, only 88 were listed on the stock exchange, and some were even retained under a system of classified stocks. Danish corporations are therefore able to remain more autonomous from stock market influence and to a large extent to include the board members they trust.

The international tendency towards the fracturing of corporate elites could also be attributed to the inner circle's reduced need for coordinated political action, owing to the rise of neoliberal politics. As Mizruchi (2013, p. 225) argues 'The triumph of big business over the constraints of government and organized labor had removed the need for a united front', echoing Useem’s (1982) observation that the cohesion of the inner circle derived in part from 
the extent of the political opposition to corporate interests. Hence the structure and outlook of different national corporate elites can be tied to the particular varieties of capitalism seen in different national settings (Cárdenas, 2012; Morgan, 2015). The social organization of the Danish corporate elite can thus shed light on whether the fragmentation of business elites is also a fact in coordinated market economies (Hall \& Soskice, 2001).

Two features of Denmark's political economy suggest that constraints imposed by the state and organized labor in a corporatism-based 'negotiated economy' (Pedersen 2006) require business to maintain its classwide coherence. While Denmark has not been left untouched by the general tendency for welfare state retrenchment (Korpi \& Palme, 2003), it remains a decommodifying welfare state (Esping-Andersen, 1990), where high levels of income redistribution and taxpayer-funded social services create a relatively equal and affluent society as measured by the Gini coefficient, with high GDP per capita levels (Campbell \& Hall, 2006). Moreover, the trades unions are still comparatively strong, if declining, with union density at about 66.8\% in 2013 (Visser, 2015). However, the strength of the trades unions has not simply weakened the position of capital; rather, cross-class alliances have been forged (Swenson, 1991) tying union leaders to the corporate world through unionowned banks and mandatory employer-employee-controlled pension funds (Ebbinghaus \& Wiß, 2011). That leaves union and business association leaders as the governors of key institutional investors with a longer-term focus on employment (Pedersen 2006). However, recent declines in union density, levels of equality, and corporatism (Blom-Hansen, 2001) are challenging this status quo. Thus, the role of union leaders as both members of and political challengers to the corporate elite remains unclear. At the same time, business associations remain the key political actors in the corporate world, both as lobbyists and through their involvement in government (Binderkrantz, Christiansen \& Pedersen, 2014). This adds to the 
paradox of the status of the inner circle in Denmark. Does a negotiated economy based on cross-class alliances remain a place where capitalists have to unite, even outside their business associations?

\section{Theory: The notion of the inner circle}

Michael Useem's (1984) concept of 'the inner circle' provides a framework capable of exploring the social organization of the corporate community by its interlocks. The inner circle is a cohesive segment of the capitalist class, defined by Useem (1978, p. 225) as 'the set of people who own and/or manage business firms', organized through interlocking board memberships as the basis for a classwide rationality representing the interest of big business at large. This inner circle is, in turn, shown by Useem $(1978,1979,1982)$ to be the most politically active of the corporate elite, featuring for example in policy planning groups, business associations, exclusive social clubs, and on university boards. The inner circle both facilitates the formation of class interest and represents this interest among other elites. In emphasizing the creation of class cohesion through social interaction within the elite, Useem combines class theory with a current of thought running in classic elite theory from Mosca (1939) and C. W. Mills (1956) to studies of corporate interlocks (Allen, 1974; Mintz \& Schwartz, 1981; for review, see Mizruchi, 1996; Scott, 1991), in which an elite is identified by its integration into an organized social group.

As a result, the inner circle is not a distinct group with clearly marked boundaries, but an axis of intra-group centrality within the capitalist class (Useem, 1979). Its extensive networks create cohesion within this elite group through ties of friendship, kinship, ownership, clubs, business associations, and boardroom interlocks (Cornwell \& Dokshin, 2014). Furthermore, the cohesiveness created by these networks is in turn enhanced if the members form a status 
group exhibiting social closure and shared values and manners (Domhoff, 1975; Useem, 1978), thus forming a ‘class-specific habitus' (Hartmann, 2000). These connections serve many purposes, but an extended 'business scan’ is of particular importance (Useem, 1982). By tapping into the flow of information that circulates within these networks, the directors and their corporations gain privileged information on the prospects for other corporations. By maintaining direct contact with government officials, the directors gain insight into the workings of the political apparatus. But these information channels are also conduits for reputation and social control.

Maneuvering multiple directorates, boardrooms, and business associations can be a tricky business, because of questions of loyalty towards different corporations and the corporate community as a whole. As a result, formal and informal rules limit the inner circle's scope of action. Those who have the 'capacity to transcend the immediate imperatives of his or her own company to express a broader vision' (Useem, 1982, p. 216) become central to the inner circle: these are the individuals who come to embody its classwide rationality. Classwide rationality differs from the diverging, uncoordinated, and atomistic interests of the corporations by promoting ‘the broader needs of big business' (Useem, 1982, pp. 201-2). It is important to note that classwide rationality is not a neutral concept-any definition of the interests of an entire class is likely to be biased towards the interests of the dominant corporations (Fligstein, 1996) — and rather, the inner circle is able to successfully legitimize its interpretation of the class interest. The cohesive network that is the basis for the formulation of class interest is what defines the inner circle, other business elite definitions aside. Those who are most likely to embody a classwide rationality are not necessarily the CEOs of the largest corporations or the wealthiest owners (Useem, 1982). 
Since the work of Berle and Means (1932), there has been an on-going discussion about whether CEOs can be considered part of the capitalist class when ownership was becoming more dispersed. It was suggested that the diffusion of ownership would entail a loss of capitalist control and a diminished focus on profits. Although the disintegration of ownership and control was seriously questioned (Zeitlin, 1974), the notion of a classwide rationality rests on the social connections between management and ownership through corporate interlocks (Useem, 1979). Thus inner-circle membership cannot be ascribed through the divergent methods of identifying class position-ownership of the means of production or being in a position to appropriate surplus labor (see discussion in Resnick \& Wolff, 2003; see also Wright, 1997). Inner-circle membership requires being part of a social group integrated through one's position on the governing bodies of large corporations. Through the multitude of interlocks, the inner circle also differs from corporate elites, which by definition comprises those who hold a position of command in those corporations (Scott, 2003).

Politically, the inner circle can be seen as informal representatives. To the extent that the corporate community manages to gain access to other spheres of power, those who are innercircle members will, according to Useem (1984), be more likely to take part. This is certainly the case for business associations, cultural organizations, federal and government advisory panels, and university boards (Useem, 1978, 1979). Furthermore, when, say, government officials seek candidates for public positions, they may acquire recommendations from prominent business leaders already in public positions (Useem, 1984). A cohesive inner group both provides a common framework and secures the promotion of its own members. Although this does not mean that inner-circle members necessarily dictate public opinion or are in a financial position to promote certain causes, the inner circle is nevertheless characterized in other influential networks as the representatives of the capitalist class. 
If corporate interlocks in Denmark can be said to display the characteristics of an inner circle, we should thus observe (i) overlapping social circles, creating a social group, (ii) similar social characteristics within this group, and (iii) a group that acts as the primary political representatives of the wider corporate community.

\section{Data: The networks of the entire corporate elite}

The data used in our study to identify Denmark's inner circle comprises the names of the board members and management of the top thousand corporations by turnover as of March 2012. Data on board membership and corporation size comes from the Danish Corporate Register. To that we have added 36 independent subsidiary firms of these corporations, ${ }^{2}$ the 28 members of the Danish Venture Capital and Private Equity Association, and the stateowned Finansiel Stabilitet, which acts as receiver for failed banks. After removing nonindependent subsidiaries, the data comprises 1,037 boards, with 7,065 positions held by 6,154 individuals. This data is fairly inclusive and the differences in size among the corporations are notable: the smallest has a turnover of just DKK 304 million (US \$53 million), whereas the largest has a turnover of DKK 315 billion (US \$55 billion). The top 100 corporations account for $68.3 \%$ of the total turnover of the 1,037 corporations.

The network data is combined with data for business association committee membership, governing boards of academic and cultural institutions and foundations, membership of political committees, and the like. This data comes from a survey, conducted by the authors, of all institutionalized influence and prestige networks in Denmark(the data is described further in Ellersgaard and Larsen, 2015). Biographical material for the social homogeneity of the inner circle was gathered from Kraks Blå Bog (Who’s Who), company websites, profiles on LinkedIn, and newspaper articles, and is thus primarily self-reported. We found full 
information on almost two-thirds of all directors (105 of 171), with information on social background and place of birth the least comprehensive (see Table 2).

\section{Methods: Reconstructing the methodology of inner circles as the core of the corporate network}

One might argue that selecting more than a thousand corporations in a small country like Denmark is too inclusive. The main methodological purpose behind this network of the entire corporate elite is to secure the inclusion of all relevant but still fairly comparable corporate ties that might facilitate cohesion and the diffusion of reputation. Non-prestigious boards are deliberately included, with the result that the issues of the scale of ranking (see Carroll \& Fennema, 2004; Kentor \& Jang, 2004) are less important in this case.

While we have data on affiliated memberships in other sectors, we have chosen to restrict the network analysis to the corporate boards. One of the main ambitions of this paper is to investigate whether the inner-circle members are more likely than the corporate elite in toto to achieve attention and positions of influence from other sectors and elites. If we had used public commissions as the core identification process, for example, we would have ended up with a circular logic, using centrality in a cross-sectorial network to explain brokerage between the corporate elite and other sectors. By excluding non-corporate affiliations— 'the social mosaic' (Barnes, 2015, p. 2)-we would likely underestimate the cohesion in the corporate network, thus trading analytical clarity for precision in the core identification, and leading us to exclude several top CEOs because they only hold one directorship. It should be noted that corporate interlock data is widely available, while data on affiliations in other sectors is considerably rarer. By restricting the social network analysis to corporate 
interlocks, we indicate how far you can get with corporate networks and still construct measures that are correlated to networks across sectors.

Within the Danish corporate elite, the network of the connected comprises the 3,166-strong group of corporate elite members who are connected to one another. If there were an inner circle in the Danish corporate network, it would be found in this group and not in the second largest, which has only 28 directors. However, many members of the connected corporate elite do not themselves form ties, but are connected only through the cliquey nature of company boards: if just one board member has ties to other boards, everyone on those boards is connected to the second degree. Thus we have restricted parts of our analysis to the 514 board members and directors who hold more than one position within the largest component of the corporate network, the network of linkers. This group of 514 linkers would usually be regarded as the inner circle (Heemskerk \& Fennema, 2009; Useem, 1982). When the number of boards increases, this definition rapidly decreases in selectivity. The diameter-the longest path length within the component—is still 13 degrees in the network of linkers, which makes transmission of actual information along these long paths very unlikely.

[FIGURE 1 near here, please]

Any search for a cohesive elite group has to tackle the demarcation of the core group (Laumann, Marsden, \& Prensky, 1983). In order to identify a more cohesive subgroup, cluster analysis was used here as a heuristic tool. A measure of proximity using overlapping social circles (Alba \& Kadushin, 1976), it calculates distances between all linkers, which are in turn divided into clusters by a hierarchical agglomerative cluster analysis. The advantage of this procedure is that the linkers are placed in mutually exclusive typological groups. The measure of overlapping circle proximity is identified using the shared overlap of linkers' 
third-degree neighbourhoods. A proximity measure ranging from 1 (total overlap of thirddegree neighbourhood) to 0 (no overlap) is created for each pair of linkers (see Figure 1). Thus linkers are regarded as close and potentially part of a certain circle, to the extent that a large proportion of their network shares the same members and that these ties in turn are composed of the same linkers. The third-degree neighbourhood has the advantage of measuring the degree centrality of the second-degree neighbourhood. As a result, individuals with relatively selective but central, direct contacts will have high proximity scores, because their third-degree neighbourhood grows rapidly in size and therefore is more likely to overlap with others. Looking at neighbourhoods also allows us to include both parent companies and subsidiaries, since inner-circle membership in this procedure is not decided by numbers of memberships but by shared connections.

As the clustering algorithm cuts the network into clusters, the group having the largest share of all ties is analysed. At the partition before this cluster no longer has half of all ties, the procedure is terminated. In this case, 343 linkers are excluded from the network, leaving us with 171 members of a more cohesive network: the inner circle, as we define it. The entire procedure is summarized in Figure 2. When comparing the inner circle as clusters are gradually cut away (see Appendix I), the procedure works much like peeling layers of an onion. Less integrated parts of the inner circle are excluded one by one. The excluded clusters do not form a single connected group, but subgroups hanging onto different parts of the inner circle. A common denominator is provided within each cluster, for example, individuals connected on boards due to cross-ownership of less prestigious firms. The advantage of the procedure used, as opposed to different types of modularity maximization and community detection analysis, lies in the fact that the procedure does not divide the network into different fractions, but rather removes different subgroups, much like peeling an onion. 
[FIGURE 2 near here, please]

The decision to end this clustering procedure is of course based on an estimate rather than on strong objective criteria, and yet it does reflect both qualitative and quantitative concerns. Thus, the clustering procedure was concluded after four subgroups were removed from the inner circle, because a further reduction would reduce the number of ties from the network of linkers by more than a half to $44.5 \%$. Most importantly, the fifth cut-off would exclude several corporate leaders known qualitatively to be key business representatives. The members of the inner-circle cluster have the highest average degree, closeness and betweenness centrality, with all members of the inner circle connected to one another in the same component, and the diameter of the inner-circle network should shrink as clusters are peeled off. Hence the inner circle is the cluster in the network of linkers that (i) still holds more than half of all ties, (ii) has the individual with the highest average degree, closeness centrality, and betweenness centrality, and (iii) that does not exclude key corporate leaders.

A central inner circle of 171 members within the network of linkers has been identified (see Table 1 and Figure 3). ${ }^{3}$ These inner-circle members are on average tied to 11.0 other linkers, compared to an average of 7.3 for all linkers. Added to this, the distance between the members of the network is reduced significantly. Unsurprisingly, given the reduced size of the network, the average path length within the network of the inner circle drops from 4.3 in the network of linkers to 2.8 in the inner circle. With no path longer than five degrees inside the inner circle, this suggests a group with very high connectivity. However, inner-circle cohesion is not further improved by the same directors sitting on several boards together (Heemskerk \& Fennema, 2009); rather, the share of multiple ties drops from $9.4 \%$ in the networks of linkers to $7.8 \%$ in the inner-circle cluster. Some of the multiple ties outside of the inner circle reflect ownership structures within conglomerates, where several subsidiaries 
share board members from the holding company. These relations are less frequent in the inner circle than among the linkers. The inner circle connects 205 corporations, 96 of which are from among the top 200 corporations in Denmark. The network of linkers in total connect 475 corporation, 143 of which are top 200 corporations.

[TABLE 1 near here, please]

\section{Results}

\subsection{Who is in the inner circle? The reproduction of a common, unifying culture}

Aside from sharing connections through membership of the same (corporate board-based) social circles, other traits may create greater cohesion within the dominant segment of the corporate elite. A shared educational background, along with an elitist social background, helps form the elite consciousness (Bourdieu, 1996; Hartmann, 2000; Useem \& Karabel, 1986) and ensures a feeling of common trust within the circle. Generally speaking the members of the Danish inner circle do share common traits (see Table 2). More than five out of six (84.2\%) inner-circle members are employed only within the corporate world (see Table 2); $52 \%$ hold an executive position, of which $59 \%$ are in one of the top hundred corporations by turnover and the remaining $48 \%$ are professional board members. These last are often former executives and have no full-time affiliation to one corporation or similar; rather, they make their living by serving as non-executive directors. The members of the inner circle are at or just past the apex of their careers, with the median and average age being 57.7 years, with a standard deviation of only 7 years. With no inner-circle members younger than 41 years and a skewed gender distribution, this is an old boys' network in all senses of the term. 
Indeed, only 14 of the 171 members (8.2\%) of the inner circle are women, further underlining the social homogeneity and class-specific cultural norms, where mastery of qualities traditionally ascribed to men is an advantage (Heemskerk \& Fennema, 2014). In the corporate elite as a whole, $13.6 \%$ of the positions are held by women, indicating that even after gaining access to company boards, women are still excluded from the networks that form and validate classwide rationality. There are no signs that women in the inner circle have particularly good network positions and they are not more frequently linked to one another. This supports claims of a token female presence (Kanter, 1977) rather than the empowerment of women's networks to challenge the cohesion and cultural homogeneity of the inner circle.

[TABLE 2 near here, please]

Only a few inner-circle members have careers outside the corporate sector. These are two academics associated with business schools, six lawyers, one lone serving politician, ${ }^{4}$ three central members of the farmers' organizations, and five labor union leaders. The union leaders not only sit on the boards of banks and media companies owned by the unions, but also hold positions in state enterprises such as Danish Railways and, most importantly, employer-employee-controlled pension funds, some of which are the largest institutional investors in the country and play an active part in shaping corporate governance in Denmark (Rose, 2007). The union leaders in the inner circle also epitomize the cross-class alliances of the Danish labor market. Thus, it is primarily the leaders of the strong unions with direct ties to industry who are included in the inner circle. Most notably, the leader of the metalworkers' union (Dansk Metal), Thorkild E. Jensen, has the third highest number of connections of all members of the corporate elite, while also being part of the social networks traditionally associated with the industrialist elite, such as the Academy of Technical Science and the 
Foundation of Entrepreneurship. Although it may be difficult to see these individuals as representatives of a classwide capitalist rationality, they may still be well known enough to be considered generally acceptable and non-subversive, akin to the 'new men of power' described by Mills (1948). Thus the presence of labor union leaders in the inner circle should be seen as a remnant of a Danish corporatist capitalist economy based on cross-class alliances, as opposed to an inner circle fighting for the interests of untamed capitalism.

Fewer than two-thirds of the inner-circle members have higher degrees or doctorates, which is comparable to the top Danish CEOs (Author AI), but significantly fewer than would be expected in e.g. France or Germany (Hartmann, 2010;). Their degrees are not very prestigious academically speaking, as none of the academic qualifications obtained by innercircle members have ever been among the top 25 courses as determined by the average grade required for admission, the sole criterion used since 1979. However, the inner-circle members originate from a select few university programs. Only four of the eight Danish universities and business schools have more than one inner-circle member among their alumni, ${ }^{5}$ and only $12.3 \%$ of the inner-circle members have a university background outside business, economics, law, or engineering. The alumni of the various principal programs do not appear to form more cohesive subgroups within the inner circle. Thus little seems to suggest an internal division of the inner circle by professions.

The social origin of the 105 individuals for whom we have managed to trace parental occupation is exclusive by Danish standards. More than half of their fathers had jobs at the top of the corporate hierarchy and/or were managers or professionals. The parents of 23 inner-circle members (13.5\%) are listed in Kraks Blå Bog, the Danish equivalent of Who’s Who, suggesting an elite background. The birthplaces of the inner-circle members are as geographically dispersed as the general population. This is somewhat surprising, as the elite 
in Denmark is otherwise concentrated around Copenhagen, the capital. It may suggest that the inner circle is recruited from a broader upper stratum based on habitual disposition rather than from a socially integrated metropolitan elite, perhaps because of the strong provincial and agricultural ties of Danish business. The general principal of admission to the inner circle appears to be having the right dispositions in the form of interests, manners, and ethics, rather than having inherited resources, such as connections and wealth. The differences in habitual dispositions between the middle and working classes may therefore explain the massive under-representation of people with working-class backgrounds. There is little indication of network ties or more cohesive subgroups based on shared social background, which along with the lack of elite school connections indicates that the Danish corporate elite is not organized according to an 'upper-class principle’ (Useem, 1982, p. 201). However, the strong similarities in the social profile show that the inner circle is not just a group that shares structural properties within the wider corporate network-it is also a status group based on an old boys’ network (cf. Heemskerk, 2007, pp. 79-81).

\subsection{Inner-circle membership and political representation}

So far, we have seen that the Danish corporate elite's networks seem to have a highly cohesive central circle. And yet one core feature must still be present before it is possible to identify this group as an inner circle-namely, the prerogative of being the networks' primary ambassadors in other spheres of power. Inspired by Useem $(1978,1979)$ we have thus explored the political representation of the inner circle, as measured by their structural position to potentially influence governing boards or other prestigious affiliations (see Table 3). These institutions also correspond to the subfields in the field of power identified by Bourdieu $^{6}(1996)$ that ensure inner-circle members have the opportunity to engage in the exchange of different forms of capital, giving their resources 'transferable value' (Khan, 
2012, p. 262). Although the other business elite groups in total outnumber inner-circle members in these diverse influence networks, it is also clear that members of the inner circle are far more likely be part of all of these types of networks than are other members of the wider business elite. As the following summary of our findings on political representation in different spheres will show, the members of the inner circle are not the only political representatives of the corporate elite, but are by far the most likely. The logic of their inclusion in other influence networks appears similar to the principles behind their inclusion in the inner circle.

\section{[TABLE 3 near here, please]}

Perhaps the most important and least surprising of the inner circle's spheres of political representation is the various business or employers' associations, along with their branch- or policy-specific committees. This institutional setting is also the most important institutional site where which the inner circle can present and impose its interests as the interests of the wider corporate class. More than one-third of the members of the inner circle are on the committees of Danish business associations, compared to less than one-fifth of the linkers and less than one-tenth of the rest of the corporate elite. More than $40 \%$ of the inner-circle members who sit on a business association committee sit on one of the fifteen central committees. Furthermore, almost $10 \%$ of all members of the core committees-which include various specialists from both corporations and business associations-also belong to the inner circle.

Politicians and civil servants are made aware of corporate policy interests through various channels. These include lobbying, direct personal meetings, and other social events. However, these contacts between top bureaucrats, politicians, and corporate stewards are also 
institutionalized in commissions, councils, and the advisory bodies of governmental agencies. Almost $15 \%$ of inner-circle members have participated in advisory bodies, councils, and commissions established from 2005 and onwards. More than one-third of all corporate elite representatives with seats on official commissions are members of the inner circle, meaning that the proportion of inner-circle members in core commissions is more than ten times greater than the rest of the corporate elite. When government wants to include the corporate community in policy debates, it is thus often the inner circle they turn to. Given the tendency to homophily in social networks (McPherson, Smith-Lovin \& Cook, 2001) and the social homogeneity of the inner circle, the recommended candidates could often be inner-circle members or their immediate networks.

By being in a structural position to influence universities, the inner circle may help shape the skill sets of future employees while also influencing research agendas towards yielding a competitive advantage. Making the voice of business heard in the academic world may involve funding research through foundations and membership of the boards of academic institutions, including university governing boards, advisory boards of university departments or national research centres, and various higher education committees. Members of the inner circle are over a hundred times more likely to participate in these networks than are the members of the corporate elite who are not connected to the large component of corporate interlocks. Of the governing boards of the eight Danish universities, one-third (5 of the 15) of the university board members who are part of the corporate elite are also part of the inner circle. The academic field appears to be quite selective when including business representatives on its boards, and the prerequisites seem to be heavily associated with innercircle membership. 
Further, membership of the boards of museums of art or history, theatres, and opera companies is another structural opportunity for business representatives to defend ostensibly upper-class culture. Even if only 3.5\% of inner-circle members sit on these boards, the inner circle is still disproportionately represented compared to other parts of the corporate network. However, where the social and political legitimation of corporate interests is at stake, rather than merely the reproduction of 'high culture', we see a stronger representation of the inner circle in the production of public opinion: $15 \%$ of inner-circle members sit on the boards of broadcast media companies, newspapers, publishers, and the five major think tanks, with the inner-circle members three times more likely to sit on these boards than even the linkers. As an indicator of social capital outside the boardroom, participation in the VL network—groups of around 30 members from business, the civil service, the media, and academia, who meet informally once a month—offers a glimpse into network cultivation strategies among the corporate elite. Almost half of the inner-circle members are active in the VL groups and 28.8\% of inner-circle members are part of the nine core groups, identified by the prestige of their fellow members. ${ }^{7}$ Access to diverse top-level networks thus appears to be bound up with the logic of inclusion in the inner circle, indicating the close links between social and symbolic capital (see also Cousin \& Chauvin, 2012).

Inner-circle members hold positions that bestow high symbolic capital on their holders more often than do other members of the corporate elite. This adds to the generalized trust in the good name and honour of inner-circle members (Bourdieu, 2005). Membership of the boards of one of Denmark’s 1,394 publicly registered foundations can be seen as an indicator of symbolic capital. These foundations administer the fortunes and charitable activities of Denmark's richest dynasties, and as a result are a useful indicator of the social standing of their directors among the moneyed class. Membership of a foundation's board is also an 
opportunity to influence other sectors through donations and as a platform for intra-elite networking. Fully $45 \%$ of inner-circle members hold positions on one or more foundation board.

The honour associated with being invited to a royal event is an indicator of a person's social standing and importance within the elite, and indeed in the eyes of the government departments which assist the royal household in drawing up the guest lists. When looking at participation in major royal events-weddings, anniversaries, landmark birthdays, christenings - as well as royal hunting parties and royal dinners, inner-circle members once again appear as the primary ambassadors of the corporate elite. Since 1998, twice as many (27.6\%) inner-circle members than linkers have participated in one or more of the 73 recorded royal events.

[FIGURE 3 near here, please]

Useem (1978, p. 227) originally used the number of board memberships as an 'appropriate though imprecise' measure of inner-circle centrality. When compared to the inner circle identified in this paper the same association of board membership and inner-circle centrality is found. However, when compared with the 206 members generated by Useem's definition of an inner circle (at least three board memberships), the 171 inner-circle members identified here are 1.25 times more likely to be members of affiliations in the spheres identified in Table $3{ }^{8}$ At the heart of the corporate network, proximity is therefore a better; although more demanding, measure of inner-circle centrality. This is illustrated in Figure 3, where the size of the points relates to the number of sectors (as defined in Table 3) in which each individual holds positions. The parts of the network with the densest connections also have the most well-connected individuals across the sectors. The Matthew effect is evident. Some $25 \%$ of 
inner-circle members sit on at least three boards from sectors outside business, compared to $6 \%$ of the linkers and only $1 \%$ of the connected. Of the unconnected members of the corporate elite, $94 \%$ are not part of any board outside business, whereas only $30 \%$ of the inner-circle members hold no positions outside business. However, the somewhat arbitrary character of any classification should be remembered (see Figure 3). Just outside of the inner circle, there are several individuals, close to the inner circle, who connect across many sectors. These individuals might have had the necessary proximity were networks other than boardroom interlocks included in the definition of the inner circle. As Useem (1979) notes, the inner circle is bound together by many other ties, and further studies could try to include them as well. These reservations aside, it appears from this analysis that across all spheres of power, the members of the inner circle are the primary ambassadors of corporate interest.

\section{Discussion: The inner circle reappraised}

The concept of the inner circle was a novel concept of its time. But its definition is perhaps neither theoretically nor empirically accurate to describe the conditions under which inner circles operate as a mechanism for capitalist class organization. In brief Useem (1978) defines the inner circle as the individuals who can influence several major corporations through either board positions or ownership. However, in other passages he emphasizes the network position - reach, dispersion and centrality - of the inner circle. The inner circle is defined not as a clearly defined group but rather an axis of 'inner group centrality' (Useem 1979, p.555) ${ }^{9}$. Our methodological approach here underlines the importance of the actual ties and cohesion within the inner circle as seen by the increase in network activity in other sectors the closer we get to the inner circle group of the corporate network. This is especially pertinent when the studied network increases in size and diversity. A larger sample increases the possibility that the inner circle, defined by memberships, is "captured” by smaller clusters 
of relatively unimportant corporations, that connect to each other but not to the main component.

As a general consideration elite studies have much to gain from moving from positional samples to samples based on defining network subgroups. As high levels of network activity are indicators of engagement and peer recognition and that lets the researcher differentiate between active and passive holders of power resources. The empirical definition of the inner circle presented here is, however, still unsatisfactory as it has no requirements as to the economic strength of the corporations and directors of the inner circle. It is assumed that the most highly connected part of the network includes the major corporations, who form the backbone of the national economy. This is in fact the case in the Danish corporate network (see Larsen and Ellersgaard, under review), but could easily be different in other economies. We should therefore consider the composition of the inner circle as well as its integration.

For the inner circle to efficiently facilitate the interests of the capitalist class, we would assume that it is necessary for it to include the major controllers of economic capital within a society. In the Danish case that would be the wealthiest families, foundations, coops, corporations and unions. The inclusion of unions in the inner circle might seem dubious at first, but the Danish pensions funds, which hold substantial amounts of capital, are often part controlled by labor unions. Thus the composition of the inner circle in the Danish case reflects the general negotiated character of the Danish economy. The composition of the inner circle identified through an inductive, reproducible method as used in this study invites to comparisons between countries, from which we may learn whether there is a connected core in the corporate network and whether that core is composed in way that includes the major controllers of capital. The fact that the inner circle appears to be alive and well in Denmark, and in very different economies albeit with similar strong family ownership such as India 
(Naudet \& Dubost, 2016) suggest that ownership structure and networks could be a key explanatory factor when understanding the stability and fragmentation of corporate networks.

Furthermore, understanding the exercise of power by inner circle members cannot rest on advantageous network positions alone. Even if the cohesion of the inner circle and its structural opportunities to exert influence in other spheres is demonstrated satisfactorily, the inner circle's actual political influence is still unclear. Scholars have tried to trace corporate influence by looking at direct political sponsorship (Bond, 2007; Burris, 2005), which is commonest among the most interlocked corporations (Goerres \& Höpner, 2014), but Danish political parties are not required by law to make their political contributions public, making it difficult to follow the money. Contributions are also made through the business clubs of the two main traditional right-wing parties. Two of the most central members in the inner circle are former heads of these business clubs, and hence act as key brokers between the corporate and the political worlds. Of these brokers, Henning Kruse Petersen, chairman of the Conservative Business Club, ranks first for betweenness centrality, second for degree, and third for closeness centrality. He is a multimillionaire and a former CEO of the largest Danish mortgage provider Nykredit, and chairman of the board of the state owned wind-up bank, Finansiel Stabilitet, along with several other board positions.

Even wealthier is the second broker, Fritz Schur, chairman of the Liberal Business Club, who owns a top one-thousand corporation while also serving as chairman of the board of three of Denmark's largest state owned enterprises: the energy giant DONG, and the interScandinavian airline SAS, and the postal service PostNord. Schur ranks between twentysecond and twenty-sixth in degree, closeness, and betweenness centrality. He also plays a key part in the social elite: he holds grand soirées at his mansion and an estimated 2,000 peoplebusinessmen, royalty, politicians, and celebrities—attend his salons annually (Sandøe, 
Sindbæk, \& Svaneborg, 2012). Furthermore, in under a decade he has risen up through the honorary hierarchy of the royal court, reaching the rank of Kammerherre or chamberlain. Fritz Schur's numerous connection came together to celebrate his sixtieth birthday, where the royal family, current and former ministers of both the left and right, celebrated actors and authors, and many inner-circle members gathered to be entertained by, among others, Elton John. His social life may provide only anecdotal evidence of an otherwise closed world, but it hints at how the inner circle converts its economic resources into access to power and symbolic capital.

\section{Conclusion: The accumulation of power through networks}

Through a social network analysis of the 1,037 most important corporate boards in Denmark, we identified an inner circle of 171 board members and executives. This inner circle is the most cohesive group in a network of interlocking corporate boards. While demonstrating a high degree of cohesion within the boardrooms' social networks, the inner circle is also more connected to other spheres than the rest of the business elite. Although our data says next to nothing about the historical evolution of the corporate elite, it is precise on the current state of inner-circle integration with other spheres. From business associations to political commissions, from university and research boards to culture and media institutions, and of course royal events, still so important for establishing social status, the faces of inner circle appear with stunning regularity. This study demonstrates the usefulness of a more methodologically nuanced concept of the inner circle, inspired by the notion first developed by Michael Useem, to understand the social organization of the corporate community in the case of a negotiated economy within an egalitarian society such as Denmark. In spite of the recent deterioration and internationalization of the inner circle elsewhere, the specific position of the capitalist class in Denmark seems to ensure its continued cohesion. While the 
factors seen in inner-circle fragmentation elsewhere- the retreat of banks as key brokers, the rise of a transnational corporate community, ${ }^{10}$ and new standards of corporate governancehave not come into full force in the Danish case, its cross-class alliances could, paradoxically, be keeping the inner circle alive. Denmark's apparent egalitarianism does not prevent a socially homogenous group of businessmen, recruited primarily from the upper echelons of society, from being enjoying close ties through their membership of corporate boards and frequent invitations to join the networks of other spheres of power.

\section{References}

Alba, R. D., \& Kadushin, C. (1976). The Intersection of Social Circles: A New Measure of Social Proximity in Networks. Sociological Methods \& Research, 5(1), 77-102.

Allen, M. P. (1974). The Structure of Interorganizational Elite Cooptation: Interlocking Corporate Directorates. American Sociological Review, 39(3), 393-406.

Barnes, R. C. (2015). Structural Redundancy and Multiplicity within Networks of US Corporate Directors. Critical Sociology.

Barnes, R. C., \& Ritter, E. R. (2001). Networks of Corporate Interlocking: 1962-1995. Critical Sociology, 27(2), 192-220.

Berle, A. A., \& Means, G. C. (1932). The modern corporation and private property. Piscataway: Transaction Publishers.

Binderkrantz, A. S., Christiansen, P. M., \& Pedersen, H. H. (2014). A Privileged Position? The Influence of Business Interests in Government Consultations. Journal of Public Administration Research and Theory, 24(4), 879-896.

Blom-Hansen, J. (2001). Organized interests and the state: A disintegrating relationship? Evidence from Denmark. European Journal of Political Research, 39(3), 391416. 
Bond, M. (2007). Elite Social Relations and Corporate Political Donations in Britain. Political Studies, 55(1), 59-85.

Bourdieu, P. (1996). State Nobility - Elite Schools in the Field of Power. Cambridge: Polity Press.

Bourdieu, P. (2005). The Social Structures of the Economy. Cambridge: Polity Press.

Bühlmann, F., David, T., \& Mach, A. (2012). The Swiss business elite (1980-2000): how the changing composition of the elite explains the decline of the Swiss company network. Economy and Society, 41(2), 199-226.

Burris, V. (2005). Interlocking Directorates and Political Cohesion among Corporate Elites. American Journal of Sociology, 111(1), 249-283.

Campbell, J. L., \& Hall, J. A. (2006). Introduction: The State of Denmark. In J. L. Campbell, J. A. Hall, \& O. K. Pedersen (Eds.), National Identity and the Varieties of Capitalism - The Danish Experience (pp. 1-49). Copenhagen: DJØF.

Cárdenas, J. (2012). Varieties of corporate networks: Network analysis and fsQCA. International Journal of Comparative Sociology, 53(4), 298-322.

Carroll, W. K. (2010). The making of a transnational capitalist class: Corporate power in the 21st century. London: Zed Books.

Carroll, W. K., \& Fennema, M. (2004). Problems in the Study of the Transnational Business Community: A Reply to Kentor and Jang. International Sociology, 19(3), 369378.

Carroll, W. K., \& Sapinski, J. P. (2010). The Global Corporate Elite and the Transnational Policy-Planning Network, 1996-2006. International Sociology, 25(4), 501-538.

Christiansen, P. M., \& Togeby, L. (2007). Elite Transformation in Denmark 1932-1999. Comparative Social Research, 23, 35-54. 
Chu, J. S. G., \& Davis, G. F. (2016). Who Killed the Inner Circle? The Decline of the American Corporate Interlock Network. American Journal of Sociology, 122(3), 714-754.

Cornwell, B., \& Dokshin, F. A. (2014). The Power of Integration: Affiliation and Cohesion in a Diverse Elite Network. Social Forces, 93(2), 803-831.

Cousin, B., \& Chauvin, S. (2012). L’économie symbolique du capital social: Notes pour un programme de recherche. Actes de la recherche en sciences sociales, 193(3), 96103.

Davis, G. F., \& Mizruchi, M. S. (1999). The Money Center Cannot Hold: Commercial Banks in the U.S. System of Corporate Governance. Administrative Science Quarterly, 44(2), 215-239.

Domhoff, G. W. (1975). Social clubs, policy-planning groups, and corporations: A network study of ruling-class cohesiveness. Insurgent Sociologist, 5(3), 173-184.

Ebbinghaus, B., \& Wiß, T. (2011). Taming pension fund capitalism in Europe: collective and state regulation in times of crisis. Transfer: European Review of Labour and Research, 17(1), 15-28.

Edling, C., Hobdari, B., Randøy, T., Stafsudd, A., \& Thomsen, S. (2012). Testing the "Old Boys’ Network”: Diversity and Board Interlocks in Scandinavia. In B. Kogut (Ed.), The Small Worlds of Corporate Governance (pp. 183-201). Cambridge: MIT Press.

Ellersgaard, C. H., Larsen, A. G. \& Munk, M. D. (2013). A Very Economic Elite: The Case of the Danish Top CEOs. Sociology 47(6), 1051-71.

Ellersgaard, C. H., \& Larsen A. G. (2015). The Danish Elite Network. Connections 35 (1): 64-68. 
Esping-Andersen, G. (1990). The Three Worlds of Welfare Capitalism. Cambridge: Polity Press.

Ferris, S. P., Jagannathan, M., \& Pritchard, A. C. (2003). Too Busy to Mind the Business? Monitoring by Directors with Multiple Board Appointments. The Journal of Finance, 58(3), 1087-1112.

Fligstein, N. (1996). Markets as Politics: A Political-Cultural Approach to Market Institutions. American Sociological Review, 61(4), 656-73.

Goerres, A., \& Höpner, M. (2014). Polarizers or Landscape Groomers? An Empirical Analysis of Party Donations by the 100 largest German Companies in 1984-2005. Socio-Economic Review, 12(3), 517-544.

Hall, P. A., \& Soskice, D. W. (2001). An Introduction to Varieties of Capitalism. In P. A. Hall \& D. W. Soskice (Eds.), Varieties of Capitalism: The institutional foundations of comparative advantage (pp. 1-68). Oxford: Oxford University Press.

Hartmann, M. (2000). Class-specific habitus and the social reproduction of the business elite in Germany and France. The Sociological Review, 48(2), 241-262.

Hartmann, M. (2010). Elites and Power Structure. Handbook of European Societies, 291-323. Heemskerk, E. M. (2007). Decline of the corporate community: Network dynamics of the Dutch business elite. Amsterdam: Amsterdam University Press.

Heemskerk, E. M. (2011). The social field of the European corporate elite: a network analysis of interlocking directorates among Europe's largest corporate boards. Global Networks, 11(4), 440-460.

Heemskerk, E. M., \& Fennema, M. (2009). Network Dynamics of the Dutch Business Elite. International Sociology, 24(6), 807-832. 
Heemskerk, E. M., \& Fennema, M. (2014). Women on Board: Female Board Membership as a Form of Elite Democratization. Enterprise and Society, 15(2), 252-284.

Heemskerk, E. M., Fennema, M., \& Carroll, W. K. (2016). The global corporate elite after the financial crisis: evidence from the transnational network of interlocking directorates. Global Networks, 16(1), 68-88.

Heemskerk, E. M., \& Schnyder, G. (2008). Small states, international pressures, and interlocking directorates: the cases of Switzerland and the Netherlands. European Management Review, 5(1), 41-54.

Kanter, R. M. (1977). Some Effects of Proportions on Group Life: Skewed Sex Ratios and Responses to Token Women. American Journal of Sociology, 82(5), 965-990.

Kentor, J., \& Jang, Y. S. (2004). Yes, There Is a (Growing) Transnational Business Community: A Study of Global Interlocking Directorates 1983-98. International Sociology, 19(3), 355-368.

Khan, S. R. (2012). The Sociology of Elites. Annual Review of Sociology, 38(1), 361-377.

Korpi, W., \& Palme, J. (2003). New Politics and Class Politics in the Context of Austerity and Globalization: Welfare State Regress in 18 Countries, 1975-95. American Political Science Review, 97(3), 425-446.

Larsen, A. G., \& Ellersgaard, C. H. (under review) Who listens to the top? Integration of the largest corporations across sectoral networks. Acta Sociologica

Laumann, E. O., Marsden, P. V., \& Prensky, D. (1983). The boundary specification problem in network analysis. In R. S. Burt \& M. J. Minor (Eds.), Applied Network Analysis: A Methodological Introduction (pp. 18-34). Beverly Hills: SAGE.

Mariolis, P. (1975). Interlocking directorates and control of corporations: The theory of bank control. Social Science Quarterly, 56(3), 425-439. 
McPherson, M., Smith-Lovin, L., \& Cook, J. M. (2001). Birds of a Feather: Homophily in Social Networks. Annual Review of Sociology, 27, 415-444.

Mills, C. W. (1948). The New Men of Power: America's labor leaders. New York: Harcourt, Brace.

Mills, C. W. (1956). The Power Elite. Oxford: Oxford University Press.

Mintz, B. A., \& Schwartz, M. (1981). The Structure of Intercorporate Unity in American Business. Social Problems, 29(2), 87-103.

Mizruchi, M. S. (1982). The American corporate Network, 1904-1974. Beverly Hills: SAGE. Mizruchi, M. S. (1996). What Do Interlocks Do? An Analysis, Critique, and Assessment of Research on Interlocking Directorates. Annual Review of Sociology, 22, 271-298.

Mizruchi, M. S. (2013). The Fracturing of the American Corporate Elite. Cambridge, MA: Harvard University Press.

Morgan, G. (2015). Elites, Varieties of Capitalism and the Crisis of Neo-Liberalism. In G. Morgan, P. Hirsch, \& S. Quack (Eds.), Elites on Trial (pp. 55-80). Bingley: Emerald.

Mosca, G. (1939). The Ruling Class. New York: McGraw Hill.

Murray, J. (2014). Evidence of a transnational capitalist class-for-itself: the determinants of PAC activity among foreign firms in the Global Fortune 500, 2000-2006. Global Networks, 14(2), 230-50.

Naudet, J., \& Dubost, C.-L. (2017). The Indian Exception: The Densification of the Network of Corporate Interlocks and the Specificities of the Indian Business System (2000-2012). Socio-Economic Review 15(2). 405-434

Pedersen, O. K. (2006). “Corporatism and Beyond: The Negotiated Economy In J. L. Campbell, J. A. Hall, \& O. K. Pedersen (Eds.), National Identity and the Varieties 
of Capitalism - The Danish Experience (pp. 245-70). Copenhagen: DJØF Publishing.

Piketty, T. (2014). Capital in the Twenty-First Century. Cambridge: Harvard University Press. Resnick, S., \& Wolff, R. (2003). The Diversity of Class Analyses: A Critique of Erik Olin Wright and Beyond. Critical Sociology, 29(1), 7-27.

Rose, C. (2007). Can institutional investors fix the corporate governance problem? Some Danish evidence. Journal of Management \& Governance, 11(4), 405-428.

Ruostetsaari, I. (2007). Nordic Elites in Comparative Perspective. Comparative Sociology, 6, 158-189.

Sandøe, N., Sindbæk, H., \& Svaneborg, T. (2012). Kammerherrens nye klæder: Fritz Schur Manden og myterne. København: Jyllands Postens Forlag.

Schøtt, T. (2003). Den Økonomiske Elites Netværk. Århus: Magtudredningen.

Scott, J. (1991). Networks of Corporate Power: A Comparative Assessment. Annual Review of Sociology, 17, 181-203.

Scott, J. (2003). Transformations in the British Economic Elite. Comparative Sociology, 2(1), $155-173$.

Stokman, F. N., \& Wasseur, F. W. (1985). National networks in 1976: A structural comparison. In F. N. Stokman, R. Ziegler, \& J. Scott (Eds.), Networks of Corporate Power: A Comparative Analysis of Ten Countries (pp. 20-44). Oxford: Polity Press.

Swenson, P. (1991). Bringing Capital Back in, or Social Democracy Reconsidered: Employer Power, Cross-Class Alliances, and Centralization of Industrial Relations in Denmark and Sweden. World Politics, 43(4), 513-544. 
Useem, M. (1978). The Inner Group of the American Capitalist Class. Social Problems, 25(3), $225-240$.

Useem, M. (1979). The Social Organization of the American Business Elite and Participation of Corporation Directors in the Governance of American Institutions. American Sociological Review, 44(4), 553-572.

Useem, M. (1982). Classwide Rationality in the Politics of Managers and Directors of Large Corporations in the United States and Great Britain. Administrative Science Quarterly, 27(2), 199-226.

Useem, M. (1984). The Inner Circle. New York: Oxford University Press.

Useem, M. (2015). From Classwide Coherence to Company-Focused Management and Director Engagement. In G. Morgan, P. Hirsch, \& S. Quack (Eds.), Elites on Trial (pp. 399-421). Bingley: Emerald.

Useem, M., \& Karabel, J. (1986). Pathways to top corporate management. American Sociological Review, 51(2), 184-200.

van Veen, K., \& Kratzer, J. (2011). National and international interlocking directorates within Europe: corporate networks within and among fifteen European countries. Economy and Society, 40(1), 1-25.

Vion, A., Dudouet, F.-X., \& Grémont, E. (2015). The Euro Zone Corporate Elite at the Cliff Edge (2005-2008): A New Approach of Transnational Interlocking. In G. Morgan, P. Hirsch, \& S. Quack (Eds.), Elites on Trial (pp. 165-187). Bingley: Emerald.

Visser, J. (2015). ICTWSS Data base. version 5.0. Retrieved 20 February 2014 from http://www.uva-aias.net/207 
Wright, E. O. (1997). Class counts: comparative studies in class analysis. Cambridge: Cambridge University Press.

Zeitlin, M. (1974). Corporate ownership and control: The large corporation and the capitalist class. The American Journal of Sociology, 79(5), 1073-1119. 
Tables and figures:

TABLE 1: THE CENTRALITY OF THE INNER CIRCLE IN THE NETWORK OF LINKERS

THE CluSTER OF

ALL LINKERS THE INNER CIRCLE

$\begin{array}{lrr}\text { Edges } & 3728 & 1873\end{array}$

Density

$0.014 \quad 0.043$

Average degree

$7.3 \quad 11.0$

Diameter

13

Average path length

$4.3 \quad 2.8$

Share of multiple ties (\%)

0.094

0.078

Average betweenness centrality

833

1555

Average closeness centrality $\times 10^{-5}$

4.7

5.3

$\mathrm{N}$

514

171

Note that comparisons between the network of the inner circle and the network of connected and the entire corporate elite are not possible, as all hangers from these networks are removed. 


\begin{tabular}{|c|c|c|}
\hline & $\mathrm{N}$ & Percent \\
\hline \multicolumn{3}{|l|}{ Corporate position } \\
\hline Chief executive officer & 59 & $34.5 \%$ \\
\hline Executive & 30 & $17.5 \%$ \\
\hline Board chairman & 40 & $23.4 \%$ \\
\hline Board member only & 42 & $24.6 \%$ \\
\hline \multicolumn{3}{|l|}{ Other position } \\
\hline Corporate only & 144 & $84.2 \%$ \\
\hline Lawyer & 6 & $3.5 \%$ \\
\hline Leader, farmers’ organization & 3 & $1.8 \%$ \\
\hline Leader, trade union & 5 & $2.9 \%$ \\
\hline Professor & 2 & $1.2 \%$ \\
\hline Politician (mayor) & 1 & $0.6 \%$ \\
\hline Owner of corporation & 9 & $5.3 \%$ \\
\hline \multicolumn{3}{|l|}{ Age } \\
\hline Mean (s.d.) & 57. & (7.1) \\
\hline \multicolumn{3}{|l|}{ Gender } \\
\hline \multirow{2}{*}{\multicolumn{3}{|c|}{ Place of birth }} \\
\hline & & \\
\hline Copenhagen area & 44 & $34.6 \%$ \\
\hline Provincial cities & 46 & $36.2 \%$ \\
\hline Rural & 26 & $20.5 \%$ \\
\hline Outside Denmark & 11 & $8.7 \%$ \\
\hline Not known & 44 & \\
\hline \multicolumn{3}{|l|}{ Fathers occupation } \\
\hline Manager (or owner) & 32 & $30.5 \%$ \\
\hline Professional & 25 & $23.8 \%$ \\
\hline Junior manager & 8 & $7.6 \%$ \\
\hline Self employed & 15 & $14.3 \%$ \\
\hline Farmer & 10 & $9.5 \%$ \\
\hline White collar & 6 & $5.7 \%$ \\
\hline Blue collar & 9 & $8.6 \%$ \\
\hline Not known & 66 & \\
\hline \multicolumn{3}{|l|}{ Education type } \\
\hline Arts and humanities & 4 & $2.5 \%$ \\
\hline Social sciences & 5 & $3.1 \%$ \\
\hline Law & 11 & $6.7 \%$ \\
\hline Business and administration & 64 & $39.3 \%$ \\
\hline Economics & 30 & $18.4 \%$ \\
\hline Engineering & 25 & $15.3 \%$ \\
\hline Science or medicine & 11 & $6.7 \%$ \\
\hline Professional & 13 & $8.0 \%$ \\
\hline Not known & 8 & \\
\hline \multicolumn{3}{|l|}{ Highest qualification } \\
\hline Doctorate & 14 & $8.6 \%$ \\
\hline Higher degree & 92 & $56.4 \%$ \\
\hline First degree & 36 & $22.1 \%$ \\
\hline Professional qualification only & 21 & $12.9 \%$ \\
\hline Not known & 8 & \\
\hline Total & 171 & $100 \%$ \\
\hline
\end{tabular}


TABLE 3: INNER CIRCLE REPRESENTATION IN OTHER PART OF THE FIELD OF POWER

\begin{tabular}{|c|c|c|c|c|c|}
\hline & $\mathrm{N}$ & Percent & & $\mathrm{N}$ & Percent \\
\hline \multicolumn{6}{|c|}{ ECONOMIC FIELD } \\
\hline $\begin{array}{l}\text { Membership of all business } \\
\text { association committees }\end{array}$ & & & $\begin{array}{l}\text { Membership of core business } \\
\text { association committeest }\end{array}$ & & \\
\hline Boards=464; Members=3659 & & & Boards=15; Members=257 & & \\
\hline Inner Circle & 57 & $33.3 \%$ & Inner Circle & 23 & $13.5 \%$ \\
\hline Linkers & 67 & $19.5 \%$ & Linkers & 20 & $5.8 \%$ \\
\hline Connected & 179 & $6.7 \%$ & Connected & 40 & $1.5 \%$ \\
\hline Corporate Elite only & 149 & $5.0 \%$ & Corporate Elite only & 21 & $0.7 \%$ \\
\hline \multicolumn{6}{|c|}{ POLITICAL FIELD } \\
\hline $\begin{array}{l}\text { Membership of all commissions and } \\
\text { advisory bodies }\end{array}$ & & & $\begin{array}{l}\text { Membership of core commissions } \\
\text { and advisory bodiest }\end{array}$ & & \\
\hline Boards $=73 ;$ Members $=1038$ & & & Boards $=10 ;$ Members $=250$ & & \\
\hline Inner Circle & 26 & $15.2 \%$ & Inner Circle & 20 & $11.7 \%$ \\
\hline Linkers & 19 & $5.5 \%$ & Linkers & 6 & $1.7 \%$ \\
\hline Connected & 53 & $2.0 \%$ & Connected & 28 & $1.1 \%$ \\
\hline Corporate Elite only & 20 & $0.7 \%$ & Corporate Elite only & 5 & $0.2 \%$ \\
\hline \multicolumn{6}{|c|}{ ACADEMIC FIELD } \\
\hline $\begin{array}{l}\text { Membership of other academic and } \\
\text { research institutions }\end{array}$ & & & $\begin{array}{l}\text { Membership of university governing } \\
\text { boards }\end{array}$ & & \\
\hline Boards=1253; Members $=109$ & & & Boards $=8 ;$ Members $=91$ & & \\
\hline Inner Circle & 37 & $21.6 \%$ & Inner Circle & 5 & $2.9 \%$ \\
\hline Linkers & 20 & $5.8 \%$ & Linkers & 5 & $1.5 \%$ \\
\hline Connected & 43 & $1.6 \%$ & Connected & 4 & $0.2 \%$ \\
\hline Corporate Elite only & 6 & $0.2 \%$ & Corporate Elite only & 1 & $0.0 \%$ \\
\hline \multicolumn{6}{|c|}{ CULTURAL AND MEDIA FIELD } \\
\hline $\begin{array}{l}\text { Membership of } \quad \text { cultural } \\
\text { organization boards } \\
\text { Boards }=71 ; \text { Members }=568\end{array}$ & & & $\begin{array}{l}\text { Membership of media and public } \\
\text { opinion organization boards } \\
\text { Boards=23; } \text { Members }=449\end{array}$ & & \\
\hline Inner Circle & 6 & $3.5 \%$ & Inner Circle & 26 & $15.2 \%$ \\
\hline Linkers & 6 & $1.7 \%$ & Linkers & 16 & $4.7 \%$ \\
\hline Connected & 21 & $0.8 \%$ & Connected & 71 & $2.7 \%$ \\
\hline Corporate Elite only & 8 & $0.3 \%$ & Corporate Elite only & 32 & $1.1 \%$ \\
\hline \multicolumn{6}{|c|}{ SOCIAL CAPITAL } \\
\hline Membership of all VL-networks & & & Membership of core VL-networks & & \\
\hline Groups $=114 ;$ Members $=3823$ & & & Groups $=9 ;$ Members $=332$ & & \\
\hline Inner Circle & 75 & $43.9 \%$ & Inner Circle & 50 & $29.2 \%$ \\
\hline Linkers & 97 & $28.3 \%$ & Linkers & 24 & $7.0 \%$ \\
\hline Connected & 260 & $9.8 \%$ & Connected & 52 & $2.0 \%$ \\
\hline Corporate Elite only & 151 & $5.1 \%$ & Corporate Elite only & 9 & $0.3 \%$ \\
\hline \multicolumn{6}{|c|}{ SYMBOLIC CAPITAL } \\
\hline Membership of foundation boards & & & Participation in royal events & & \\
\hline Boards=1394; Members=7179 & & & Events $=73 ;$ participants $=7374$ & & \\
\hline Inner Circle & 75 & $43.9 \%$ & Inner Circle & 49 & $28.7 \%$ \\
\hline Linkers & 90 & $26.2 \%$ & Linkers & 47 & $13.7 \%$ \\
\hline Connected & 281 & $10.6 \%$ & Connected & 132 & $5.0 \%$ \\
\hline Corporate Elite only & 115 & $3.8 \%$ & Corporate Elite only & 50 & $1.7 \%$ \\
\hline
\end{tabular}


FIGURE 1: OVERLAPPING 3-NEIGHBOURHOODS AS PROXIMITY MEASURE

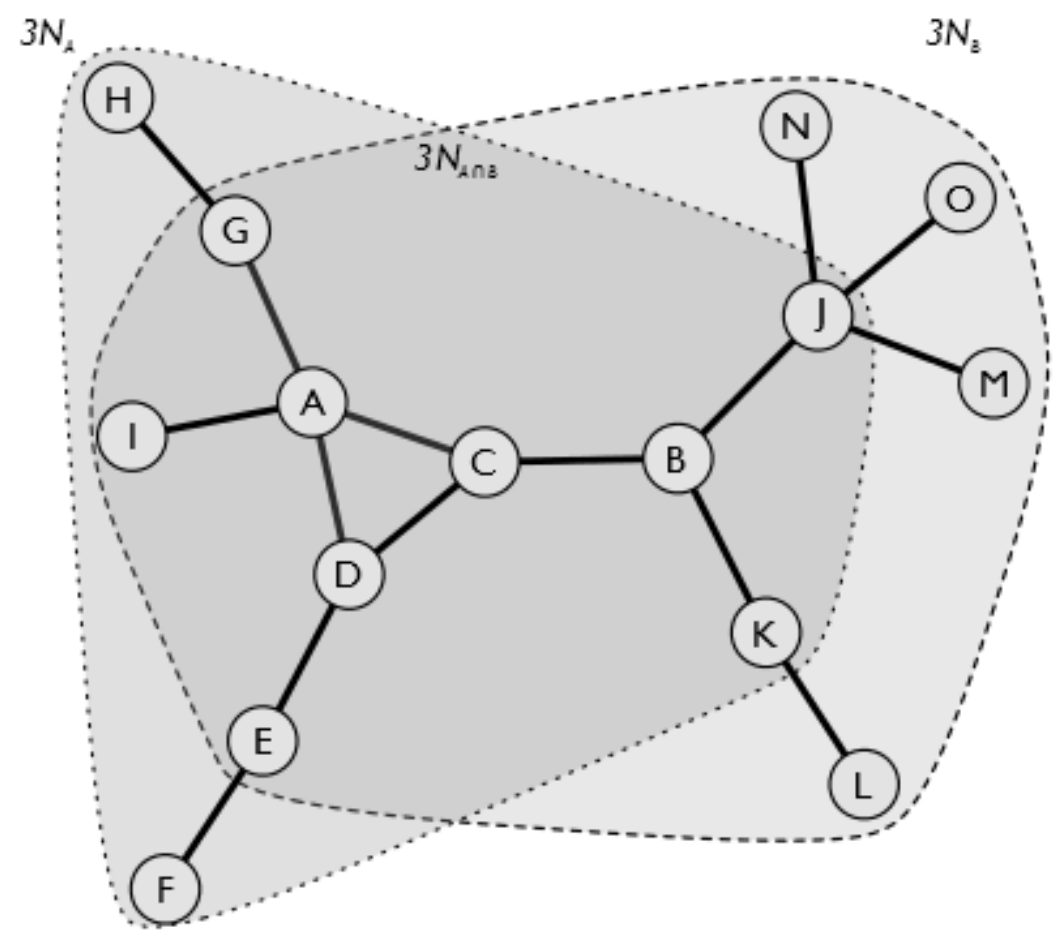

The proximity of $A$ and $B$ is determined by the shared overlap for 3-neighbourhood divided by the total size 3neighbourhood of both $A$ and $B$. In this case, the shared neighbourhood is 8 ( $A, B, C, D, E, G, I$, J and $K-1$ ) out of 14 , giving a proximity score between $A$ and $B$ of 0.571 . 
FIGURE 2: THE DIFFERENT NETWORK SEGMENTS OF THE CORPORATE ELITE IN DENMARK

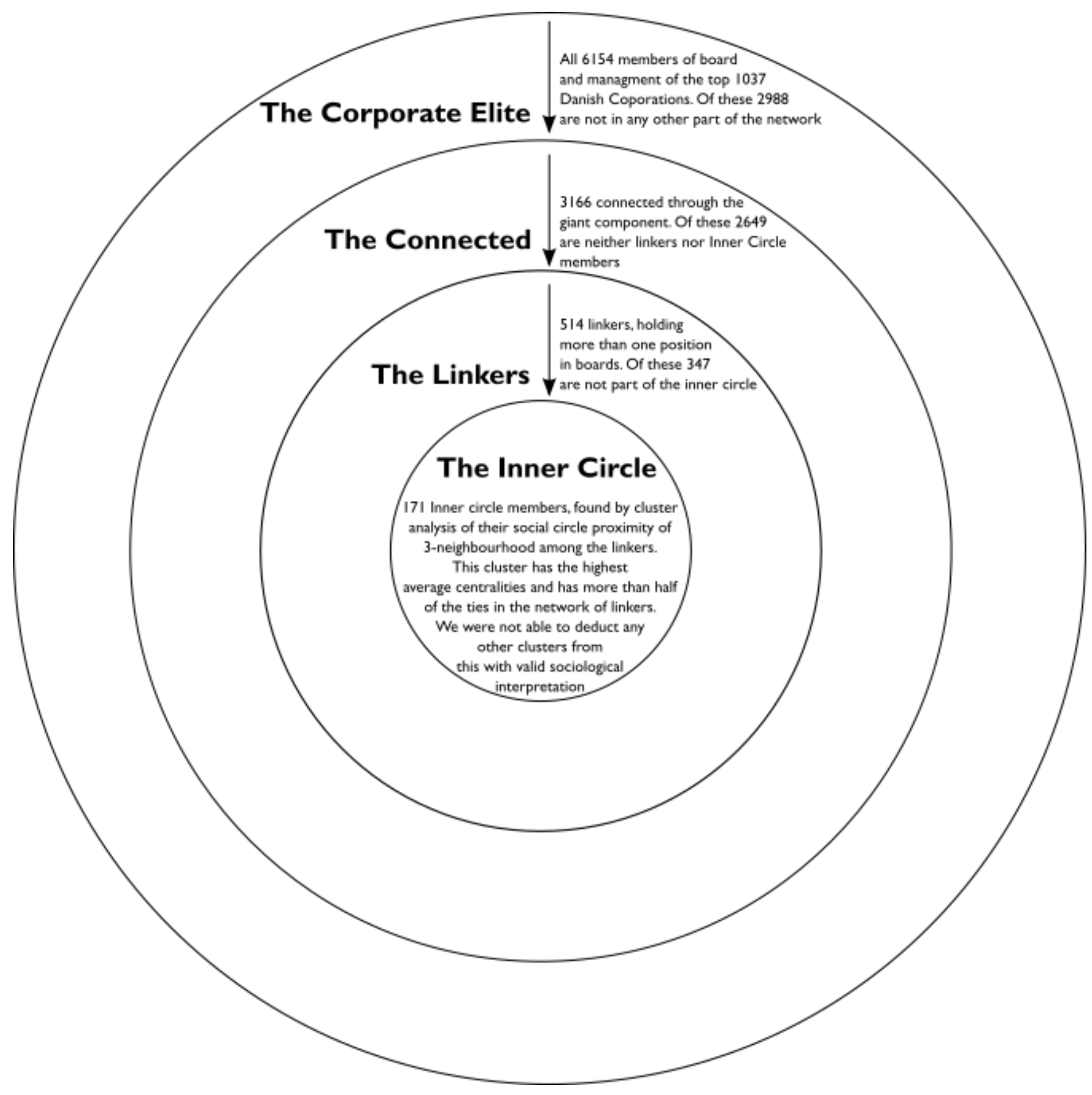


FIGURE 3: THE INNER CIRCLE IN NETWORKS OF OTHER PARTS OF THE FIELDS OF POWER

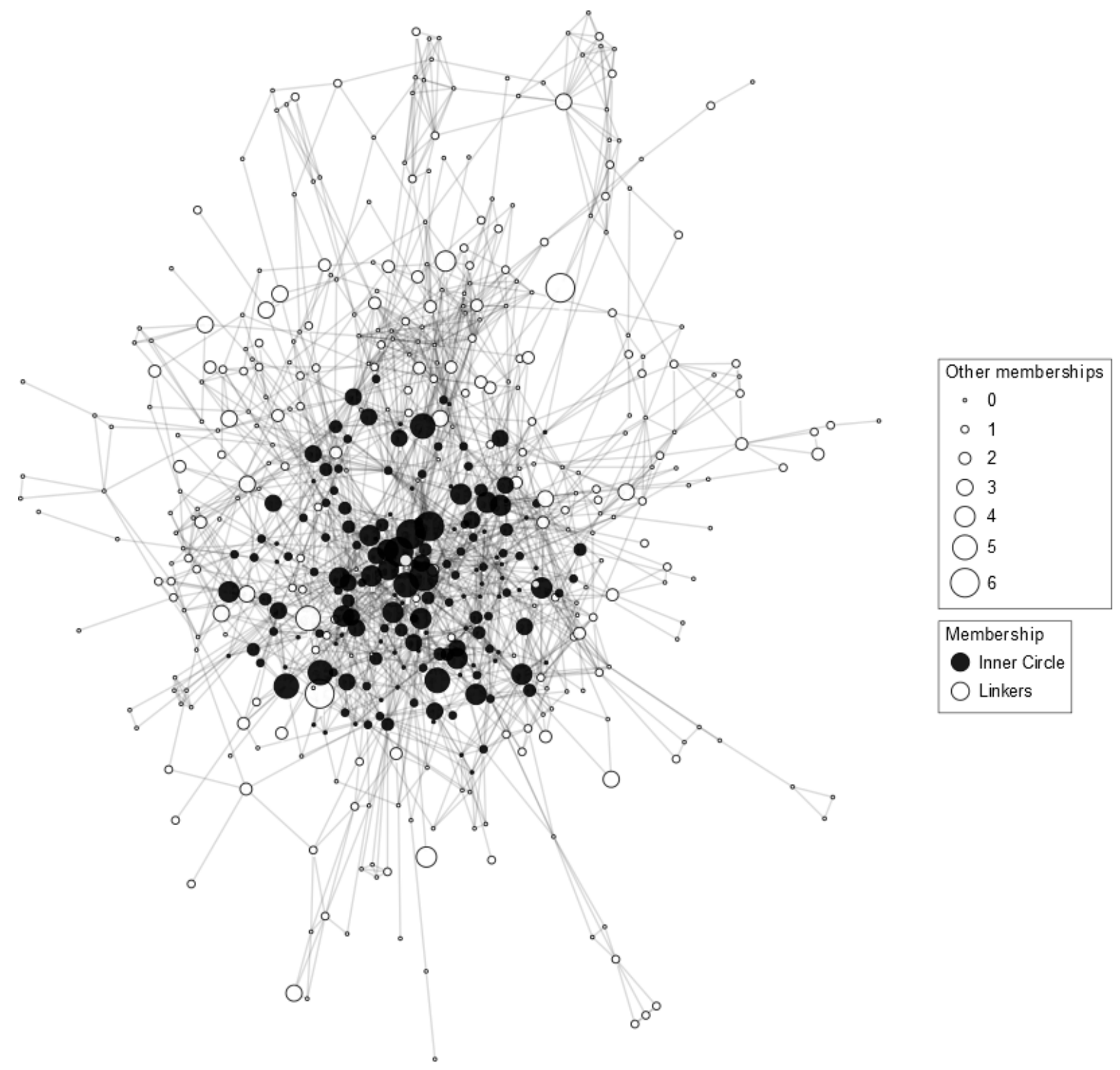

Size of nodes indicates number memberships in the nine other power networks presented in Table 3. Only the core networks of business association committees, political commissions and VL-groups are included. 
APPENDIX: CLUSTER ANALYSIS IDENTIFYING THE INNER CIRCLE

\begin{tabular}{|c|c|c|c|c|c|c|c|c|c|c|c|}
\hline & LINKERS & 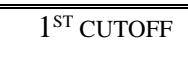 & IC I & $\mathrm{2}^{\mathrm{ND}}$ CUTOFF & IC II & 3 $^{\mathrm{RD}}$ CUTOFF & IC III & $4^{4^{\mathrm{TH}} \text { CUTOFF }}$ & IC IV & 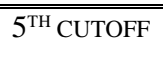 & IC V \\
\hline $\begin{array}{l}\text { Total number of clusters } \\
\text { in HAC }\end{array}$ & 1 & 2 & & 3 & & 7 & & 19 & & 33 & \\
\hline \multicolumn{12}{|c|}{ NETWORK CHARACTERISTICS OF CLUSTER } \\
\hline Number of members & 514 & 134 & 380 & 158 & 222 & 34 & 188 & 17 & 171 & 21 & 150 \\
\hline Density & 0.0283 & 0.0134 & 0.0335 & 0.0219 & 0.0418 & 0.0454 & 0.0411 & 0.0252 & 0.0427 & 0.0395 & 0.0431 \\
\hline Components & 1 & 43 & 1 & 28 & 1 & 4 & 1 & 9 & 1 & 4 & 1 \\
\hline Diameter & 13 & - & 7 & - & 6 & - & 5 & - & 5 & - & 5 \\
\hline Average path length & 4.3 & - & 3.0 & - & 2.9 & - & 2.9 & - & 2.8 & - & 2.8 \\
\hline Transitivity & 0.417 & 0.613 & 0.416 & 0.586 & 0.439 & 0.728 & 0.412 & 0.857 & 0.419 & 0.783 & 0.427 \\
\hline \multicolumn{12}{|c|}{ CHARACTERISTICS OF CLUSTER MEMBERS } \\
\hline Share of total ties & 1.0 & 0.124 & 0.876 & 0.238 & 0.638 & 0.106 & 0.532 & 0.030 & 0.502 & 0.057 & 0.445 \\
\hline Average degree & 7.3 & 3.4 & 8.6 & 5.6 & 10.7 & 11.6 & 10.5 & 6.5 & 11 & 10.1 & 11.1 \\
\hline Average closeness $\times 10^{-5}$ & 4.7 & 3.7 & 5 & 4.5 & 5.3 & 5.1 & 5.3 & 4.9 & 5.3 & 5.2 & 5.4 \\
\hline Average betweenness & 833 & 265 & 1033 & 519 & 1400 & 907 & 1489 & 824 & 1555 & 1267 & 1595 \\
\hline $\begin{array}{l}\text { Common denominator of } \\
\text { cut-off }\end{array}$ & & Minor boards & & $\begin{array}{r}\text { Minor boards } \\
\text { Specific } \\
\text { ownership } \\
\text { groups } \\
\end{array}$ & & $\begin{array}{r}\text { Bankers } \\
\text { State } \\
\text { ownership }\end{array}$ & & $\begin{array}{r}\text { Minor boards } \\
\text { Lawyers }\end{array}$ & & None & \\
\hline
\end{tabular}




\section{Endnotes:}

\footnotetext{
${ }^{1}$ However, the 1,037 corporations employed around 1,600,000 both inside and outside Denmark, which would be equal $57 \%$ of the total Danish labor force, showing their potential importance in spite of their apparent small size.

${ }^{2}$ Included subsidiary firms all have board members who are not all employed by or at the parent company board. Further, these companies all have turnovers so large that, were they independent firms, they would have been included in the data.
}

${ }^{3}$ Since this study include a broader sample of corporate boards than most comparative studies of corporate interlocks, who usually restrict themselves too look at the top 250 corporations in nation states, comparing the size of the inner circle identified is not straightforward. The corporate elite identified here is around twice as large as in other studies. If we compare the number of linkers, holders of multiple directorships, the 514 found in this study $-8.4 \%$ of the entire corporate elite-appear to be a fairly large group in a small nation state. Heemskerk (2007, p. 85) only finds 183 (10.6\%) multiple directors in The Netherlands, however from a much smaller sample. Barnes and Ritter (2001, p. 201), find 1,109 (34.6\%) in the US. Adding to this, Edling et al. (2012) report that $16 \%, 20 \%$ and 35\% of the board members in the largest 149 Danish, 250 Swedish and 157 Norwegian corporations in 2005 had multiple directorates. The comparative analysis done by Stokman and Wasseur (1985, pp. 22-3) find between 271 and 564 multiple directors, between $10.5 \%$ and $26.7 \%$ of the national corporate elites in 10 major economies in 1976. Around a third of the multiple directors in these studies hold at least three positions, roughly corresponding to the degree of linkers who are part of the inner circle is this study.

${ }^{4}$ The one politician is a mayor of a rural municipality, who serves as political representative on boards in several state owned enterprises.

${ }^{5}$ The universities with more than one alumnus in the inner circle are Copenhagen Business School (41), University of Copenhagen (30), Aarhus University (19), and Technical University of Denmark (11).

${ }^{6}$ While Bourdieu was hesitant to engage with network analysis, he nonetheless explores an affiliation network in his analysis of the French field of power (Bourdieu 1996: 365)

${ }^{7}$ The indication of the core group status of a VL group is participation in these groups of government permanent secretaries, leaders of top business associations, editors-in-chief of national newspapers, and leaders of major public institutions such as universities and museums.

${ }^{8}$ The ratio of inner circle members to holders of at least three board with regard to positions in other sectoral networks, see Table 3, ranges from 0.90 (on cultural organization boards; the only ratio less than 1.06) to 1.53 (university governing bodies).

${ }^{9}$ Useem (1979, p. 555, italics in original) underlines that the inner circle 'is a metaphor and the boundary between it and the remainder of the capitalist class is not sharp. Indeed, it is more appropriate to think of its members not as a distinct group at all, but rather as clustered near the end of a continuous differentiating axis within the capitalist class. This axis of inner group centrality ranges from those who are connected with a single major firm to those with two connections, three connections, and at the far end of the axis, many connections'. 
${ }^{10}$ So far, the challenge of the emergent transnational business community (Heemskerk, 2011; Murray, 2014) to inner-circle cohesion in Denmark seems to be limited. Only two inner circle members are members of important informal networks, the European Round Table of Industrialists and the Trilateral Commission (Carroll \& Sapinski, 2010). One sits on several boards of European Fortune 500 corporations and four Danish corporations have been able to attract foreign directors of these corporations to their boards. Several inner-circle members are connected to the group of global interlockers through boards outside Denmark as well. However, these connections do not point to the formation of an international network in competition with the coherence of the Danish network, but rather as the fruits of success, granted only to the most prominent members of the inner circle. The obligation to continue to fit into the unifying culture of the inner circle is seen by foreigners as the inner circle in Denmark. Ten of the eleven inner-circle members born outside Denmark are from other Nordic countries, primarily Sweden. 